\section{みかん作共同経営 崩壊に関する一考察}

高橋 信 正

\section{1 はじめに}

ここでのみかん作共同経営を開墾から行なうそれと 規定する，共同経営の有利性が，みかん作共同経営に 特質があるが故に変質し，共同経営を持続するにつれ て個別経営の方が有利となり共同経営は解体せざるを 得なくなる. 本稿ではこのような, 共同経営の形成と 分裂が個別小農経営にとってどのような役割を果たす かを考察する。

\section{2 共同経営の有利性}

共同経営の有利性とは個別経営に対するものである 事は明確である．開墾し植栽する段階では次のような 有利性がある. (1)開園素地取得の権利調整等の容易さ, (2)開園の場合には多額の費用を必要とするがその調達 の容易さ，(3)ブルドーザー等大型機械使用による高能 率化，(4)協業による作業能率向上等である.

それ以後の段階においての有利性は一般的なものと して次の如く考えられる。（購買販売の際の共同の有 利性は農協等の組織がその役割を果たしているので除 く）(1)労働力獲得, (2)大型機械に支えられた大規模化, (3)農政の優遇（低利率長期間の融資金貸与）。

\section{3 みかん作共同経営の特質}

みかん作共同経営の特質を求めるためにそれと他部 門共同経営との現状比較を愛媛県農林水産部「愛媛県 における農業共同経営の現状」(昭和 42 年) なる資 料で行なった。それによると次のような特質が考えら れる.こてで他部門とは酪農, 養豚, 養鷄, 園芸, し いたけ，養虫，和牛の各部門である。

(1)参加農家数が多くしかもそれが部落ぐるみという ように経営規模, 専兼業別にみて異質の農家群から構 成されている.

(2)出役可能労働日数の階層間格差が大きく, しかも
経営体への労働力供給が多く農繁期利用に関して母体 経営との競合がきびしい。

(3)多額の資本金を必要とするがてれを大部分借入金 に依存し,その後の育成過程における利子負担が大き い.

(4)投資額回収期間が長い.

(5)長期の育成期間にわたって貨金，分配金とも支払 われないのが多い。

\section{4 みかん作共同経営の阻害要因分析}

\section{個別経 営との比較}

(1)開墾と植栽段階では共同経営の有利性が働くが, 次の育成段階にはいると問題が起こる.

専業, 規模の大小, やる気の有無の両傾向の農家が 混入する場合も特質(1)ら充分にあり,その為に両者が 意欲を失する事も考えられる。

例えば愛媛県の A 農園 ( A 農園の意志により匿名 ) は構成員が 40 名でその階層は経営面積にして 1,325 $a$ から39 $a$ までの分化度があり, 現金収入では 46,074 円から 4,054 円までの格差がみられる。（昭和 41 年 度 ）また農業労㗢力も 1 人〜 4 人の差がある.とれら が A 農園の不振 ( 紙数の関係で数字は掲げ得ないが全 くの不振）の原因の一つになっている。

(2)特質(2)は出役労働日数の差が専業農家の意欲の減 退を招き，またとの事は構成員の母体の個別経営と共 同経営との摩摖，特に労㗢の競合具合が大きく起こる.

A 農園の場合, 母体経営必要時間が家族可能労働時 間を上回る一すなわち共同経営に全く学働を提供でき ない一のを月別に測ってみると全 40 戸のうち 10 月 には 17 戸，11月には 27 戸，12月には 17 戸と 多数を占め, また 40 戸全てが母体経営でみかんを作 っている.

しかるに個別経営独自が開墾した新植みかん園とそ の農家の既存のみかん園との競合とのいかんをみると， 共同経営では自家経営で使って余った学力を共同経営 に売りにいくといった形になるのに対して, 個別経営 は労力・機械・施設等の延長利用にすぎず競合になら ず反対により有効利用できる場合が多い。とてにも共 同経営を永続する際の不利性が目立つ.

(3)収益性を高めるには自己資本率が大きい事，いい かえると借入金が少ない事である。しかるにみかん作 共同経営では借入金が膨大で（自己資本率は大体三割 以下)，その利子も高額となる．資本が借入金である と収益のいかんを問わず利子は経営体外へ去り，ての 
事が共同経営を苦難に陥し入れる.

A 農園では総資本安全率 (自己資本／総資本) は 1 割にしかすぎず, 開園 6 年目にしても借入金利子が全 収入の 7 割も占めているのである. 実際全くの経営不 振でありての長期借入金の利子返済を農協より短期借 入金でまかなっている現状であるので悪循環をくり返 している.そてには多人数で借りるので無責任になり 甘えて返済能力以上の借金をする傾向がある.実際，統 計によると共同経営参加者の 1 人当たりの借入金は個 別経営のそれは 60 万円対 30 万円で前者は後者の 2 倍の利子負担が課せられる. 2 倍の生産量があげられ れば良いのだが共同経営には多くの阻害要因が働き個 別と同等あるいはそれ以下しかあげ得ていないのでそ の負担は全く重荷である.

農政の優遇という有利性を持ちながらも,それが過 当である故阻害要因に変わり共同経営はその存続を危 うくし，その有利性を個別経営に渡すのである.

(4)特質(4)はみかん作共同経営の特質ではなくてみか ん作経営の特質というべきであろう。しかしての事が あるが故に共同経営が個別経営よりも不利になるとい う事を示そう。

両者ともこの待ち時間は同じであるからそれの受け とめ方の差異如何で有利不利が決定する．そこで共同 経営に参加している一構成員農家と個別経営との持久 力を次のような側面で比較検討してみる. (1)貨金・分 配金面, (2)借入金償還面, (3)精神面 ( 経営に対する愛 着 ), (4)労働力面である.

(1)次の(5)で検討するが個別経営の方が有利.

(2)(3)でみた如く共同経営では構成員の負担能力以上 の借金を負う事になるので, 能力にあった個別経営の 方が利子償還は楽である。

(3)てれは両者が両者の経営を継続させようとする気 持の有無大小によって左右される. 当然のように共同 経営構成員が所有地以外 (所有地なのだが) の共同経 営を続けるよりも自分で開殬した農地に対する個別農 家の方が有利.

(4)個別農家の方が劣覀労働, 中途半端な時間, 中古 の機械施設等の有効利用のため個別経営の方が有利で ある。

以上のような分析結果から明らかなように無報酬期 間に対する持久力は個別経営の方がより大だと結 論される.とのように「投資額回収期間が長い」が故
の特質が共同経営にとって阻害要因に変わり規模拡大 の有利性が相殺されるのである.

(5)共同経営に参加している農家の意識は共同経営を, 母体経営を営んだ後あまった労働を消化する「労働の 場」として考える.それだから出役・出資金に対して は労賃・分配金の要求は当然と考える.しかるに個別 経営の場合は新規開墾して得た土地に対して「労働の 場」と見ず, 従来の経営の延長として考えるので, そ てで労働報酬・分配金がなかったとしても，もし従来 のもので生活が継続するならばそとを放棄することは ないであろう。とこにも個別経営の強味が見いだされ るのである。

\section{5 むすび}

前述したようにして解体した後その共有地を公平に 分けたとしても個別にとっては規模拡大になる．本質 はみかん作共同経営は小農が個別ではできない規模拡 大を果たすための一段階であるとみる。綿谷越夫氏は 共同経営を「小農範疇の拡大版」だとしているが, み かん作共同経営では小農範疇の有利性を発揮するまで にもいかず分裂し「小農経営の規模拡大」の役割を果 たす、A農園では平等に分割しても 1 戸あたり $6 a$ の 規模拡大である.

それではみかん作農家はどうすれば良いのか.

ひとつ, 有利性を生かすととである.

共同で開墾を行なうのは有利である．永続させるた めには個別経営でやるのが有利である.それで分割し て個別経営の規模拡大を行なう。そてで実際に能率の あがろ有利な作業があるのだから一例, スピードスプ レアー, 固定配管等による防除作業一その集団地でそ の作業のみを共同化する。それならば最初からそうす れば良いのだが農政の資金面の関係でまず共同経営に 入らざるを得ないのである。 ふたつ,それができないなら「待つ」ことである。 共同経営の失敗する間接の要因の多くは「人間関係」 にあるとされる.現在いかに農民が主体的にめざめたと され農村社会と家族関係が民主化されたとはいえ共同 精神の遅れ, 組織する能力の未発達, 経済人であろう とする意識の未成, 伝統的慣習的な諸力の残存等が目立 ち乙れらが熟して共同経営を行なうに適した「人間 関係」が生まれるのを「待つ」ととである. 